\title{
COMUNICACIÓN
}

\section{Nosema like organisms found in an immunocompetent human patient. First report in Central América}

\author{
MISAEL CHINCHILLA*, LILIANA REYES y OLGA M. GUERRERO
}

\begin{abstract}
Stool samples of a immunocompetent hypertense 61-year old woman were stained by the Weber et al. method and studied by electronic microscopy. Mature microsporidia spores were found and according to their diplokaryotic nuclei, as well as the typical polar filament with 12 coils, the organisms was classified as Nosema like genus.
\end{abstract}

Key words: Nosema, Microsporidia, Immunocompetent patient

\section{INTRODUCTION}

Microsporidia infections have been specially associated with AIDS patients. Primary site of infection could be the gastrointestinal tract or other sites and the genera reported are Enterocytozoon ${ }^{1}$ Microsporidium, Encephalitozoon, ${ }^{2}$ and Septata ${ }^{3}$ later described as Encephalitozoon hellem and E. cuniculi has been reported from eye lesions as well as from other tissues ${ }^{5,6}$. Pleistophora $\mathrm{spp}^{7}$ and Trachipleistophora hominis ${ }^{8}$ have been described from muscle of immunodeficiency or AIDS patients. However microsporidial infections have also been found in immunocompetent patients. It is the case of Vittaforma cornea and Nosema ocularum $^{9}$ and Enterocytozoon bieneusi ${ }^{10}$ and Microsporidium africanum or M. ceylonensis found in eye lesions. In addition Brachiola species has been related with stromal Keratitis, myositis and skin lesions ${ }^{11}$. High antibody titters against Encephalitozoon species have been reported in immunocompetent subjects ${ }^{12}$.

Microsporidia have been reported in Chi$1 \mathrm{e}^{13-14}$ and Argentina ${ }^{15}$ and thus far, the first report in Central America is the presence of $E$. bieneusi in Costa Rica ${ }^{16}$.

This paper reports, the intestinal presence of Nosema like organism in an immunocompetent human patient.

\section{DESCRIPTION OF THE FINDING}

A stool sample was collected from a hypertense 61-year old woman who had complained a three days diarrhea period with intense abdominal ache. The specimen was studied by light microscopy and stained by the Weber et al. technique ${ }^{17}$. Groups of bright pinkred organisms suggested the presence of

\footnotetext{
* Center of Research and Diagnostic in Tropical Diseases, Department of Parasitology, Faculty of Microbiology, University of Costa Rica. San José, Costa Rica, América Central. Author: Telephone number: 207-42-77 Fax number: (506):225-23-74.
} 
microsporidian spores, different in morphology to $E$. bieneusi specially regarding to the size. Part of the specimen was fixed with $3 \%$ glutaraldehyde followed by $1 \%$ osmium tetroxide, dehydrated in an ascending series of alcohol solutions, and embedded in Spurr'epoxy resin.

Ultrathin sections were cut, mounted on copper, grids and stained with $2 \%$ urany acetate and $2 \%$ lead hydroxide. The sections were studied using a Hitachi 7.100 electron microscope.

Characteristic spores end sporoblasts were detected (Figure 1). Sporoblasts and matures spores were oval in shape. Some sporoblasts

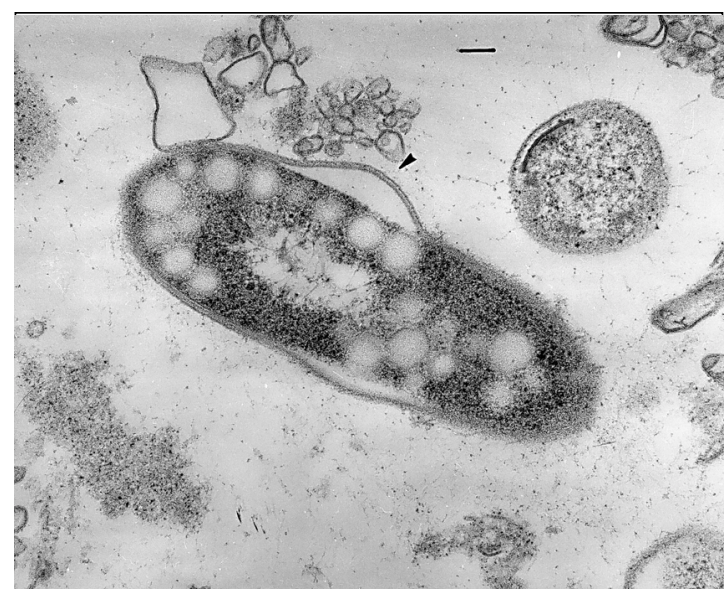

Figure 1. Mature spore with 12 coils. Note endospore layers (arrow). $(0.6 \mathrm{~cm}=0 . \mid \mu \mathrm{m})$.

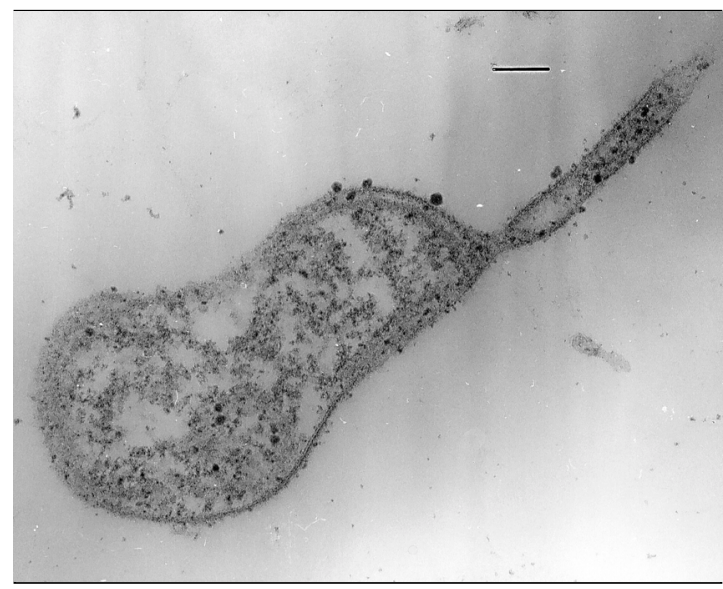

Figure 2. Tubular appendage (Initial). $(0.92 \mathrm{~cm}=0.1 \mu \mathrm{m})$ presented the characteristic diplokaryotic nuclei (Figure 1, arrow) and in the matures spores a polar filament with 12 coils was shown.

Fürthermore these spores were bounded by a two layer well-developed wall: the electrondense exospore and the electron-lucent endospore layers (Figure 1, arrow). Other interesting finding is the presence of the tubular appendages reported for Septata intestinalis (later $E$. intestinalis $^{3}$. They mentioned that this appendages "ocurr singulary, apparently originating from the sporont surface and terminating in an enlarged bulb-like structure"s. These tubular appendages are also reported for Nosema in the present study (Figure 2) and a sporoblast with complete appendage (Figure 3 ) confirms the suggestions ${ }^{3}$.

All the morphological characteristics already mentioned identify this parasite as a Nosema like microsporidia ${ }^{18}$. Human infections for this organisms has been reported from corneal lesions; such is the case of $V$. cornea (earlier $N$. cornea) and $N$. ocularum findings ${ }^{1}$. On the other hand, N. connori has been isolated from different tissues of an athymic male infant 12 and there is a report of an incidental findings of Nosema evolutive stages in muscle digested cells, present in feces from a human immunodeficient patient ${ }^{19}$. It is interesting to mention that according with Weiss (1998) many of the Nosema species has been included in the Brachida genus. It has been postulated that the

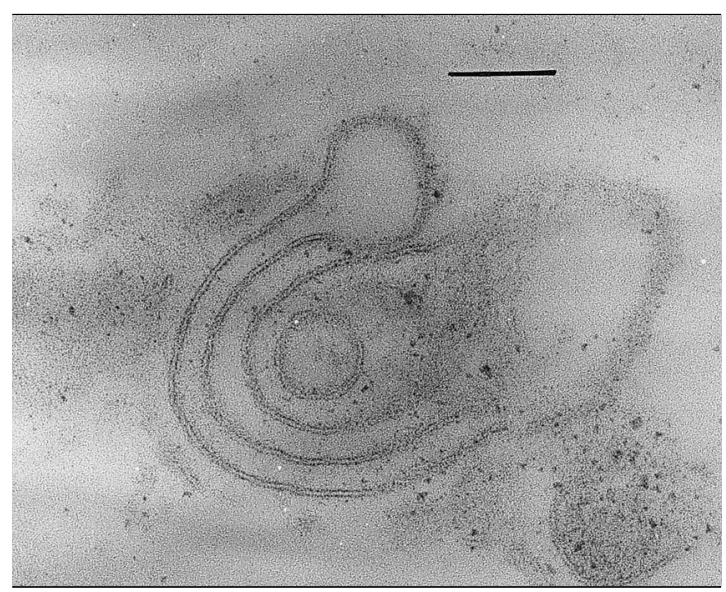

Figure 3. Tubular appendage (complete structure). (1.74 $\mathrm{cm}=0.1 \mu \mathrm{m})$ 
presence of Microsporidia organisms in fecal samples does not mean intestinal infections ${ }^{20}$ and that it could only reflect asymptomatic microsporidian carriage ${ }^{6}$ A biopsy examination, besides electron microscopy studies, is suggested for definitive diagnosis. However in our case, treatment with albendazole improved clinically the patient, even when spore excretion continued. Therefore it appears that this report do not represent an incidental findings as the report of McDougall et al. ${ }^{20}$. In addition, the report of these parasites in human feces is useful for screening purposes. On the other hand, this paper represents the first report in LatinAmerican countries of this genus of Microsporidia.

\section{REFERENCES}

1.- DESPORTES I, CHARPANTIER Y L E, GALIAN A et al. Ocurrence of a new microsporidian, Enterocytozoon bieneusi n.g. n.sp., in the enterocytes of human patient with AIDS. J Protozool 1985; 32: 250-4.

2.- WEBER R, BRYAN D A, SCHWARTZ, OWEN R L. Human microsporidial infections. Clin Microbiol Rev 1994; 426-61.

3.- CALI A, KOTLER D P, ORENSTEIN J M. Septata intestinalis n.g., n.sp., and intestinal microsporidian associated with chronic diarrea and dissemination in AIDS patients. J Euk Microbiol 1993; 40:101-12.

4.- HARTSKEER R A, VAN GOOL T, SCHUITEMA A R J, DIDIER E D, TERPSTRA W J. Genetic and immunological characterization of the microsporidian Septata intestinalis Cali, Kotler and Orenstein, reclassification to Encephalitozoon intestinalis. Parasitology 1995; 110: 277-85.

5.- DIDIER E S, DIDIER P J, FRIEDBERG D N et al. Isolation and characterization of new human microsporidian, Encephalitozoon hellem (n.sp) from three AIDS patients with keratoconjuntivitis. J Infect Dis 1991; 163: 617-21.

6.- WEBER R, KUSTER G S, VISVESVARA R T et al. Disseminated microsporidiosis due to Encephalitozoon hellem: pulmonary colonization microhematuria and mild conjunctivitis in a patient with AIDS. J Infect Dis 1993; 17: 415-9.
7.- CHUPP G L, ATTORY J, ADELMAN L S et al Myositis due to Pleistophora (Microsporidia) in patient with AIDS. Clin Infect Dis 1993; 16: 15-21.

8.- HOLLISTER W S, CANNING E U, WEIDNER W et al. Development and ultrastructure of Trachipleistophora hominis n.g., n.sp. after in vitro isolation from an AIDS patient and inoculation into athymic mice. Parasitology 1996; 112: 143-54.

9.- CALI A, MEISLER D, LOWDER C Y et al. Corneal microsporidiosis: Characterization and identification. J Protozool 1991; 38: 9215-17.

10.- WEBER R, BRYAN R T. Microsporidial infections in immunodeficient and immunocompetent patients. Clin Infect Dis 1994; 19: 517-21.

11.- WEISS L M. Microsporidia:emerging pathogenic protests. Acta Tropica 2001; 78: 89-102.

12.- VAN GOOL T, VETTER J C, WEINMAYR B et al. High seroprevalence of Encephalitozoon. J Infect Dis 1997 ; 175: 1020-4.

13.- ODDO D. Intestinal microsporidiosis in a chilean patient with acquired immunodeficiency syndrome (AIDS). Pathol Res Pract 1995; 189: 209-13.

14.- WEITZ J C. Microsporidiosis in patient with chronic diarrhea and AIDS, in HIV asymtomatic patients with acute diarrhea. Rev Méd Chil 1995; 123: 84956.

15.- VELAZQUEZ J N. Detection of the microsporidian parasite Enterocytozoon bieneusi in specimens from patients with AIDS by PCR. J Clin Microbiol 1996; 34: 3230-2.

16.- CHINCHILLA M, REYES L, GUERRERO O M, MORALES M T. Enterocytozoon bieneusi (Orden Microsporidia, Familia Enterocytozoonidae) in Costa Rica: Report of the first human case in Central América. Parasitol al Día 1997; 21: 119-22.

17.- WEBER R, BRYAN R T, OWEN R L et al. Improved light microscopical detection of microsporidia spores in stool and duodenal aspirates. N Engl J Med 1992; 326: 161-6.

18.- LARSSON J, RONNY I. Identifcation of Microsporidian genera (Protozoa, Microspora) a guide with comments on the Taxonomy. Arch Protiskenkd 1988; 136: 1-37.

19.- MARGILETH AM, STRANO A J, CHANDRA R et al. Dissemination nosematosis in an immunologically compromised infant. Arch Pathol 1973; 95: 145-50.

20.- DOUGALL Mc R J, TANDY M W, BOREHAM R E et al. Incidental finding of a Microsporidian parasite from an AIDS patient. J Clin Microbiol 1993; 31: 436-9. 